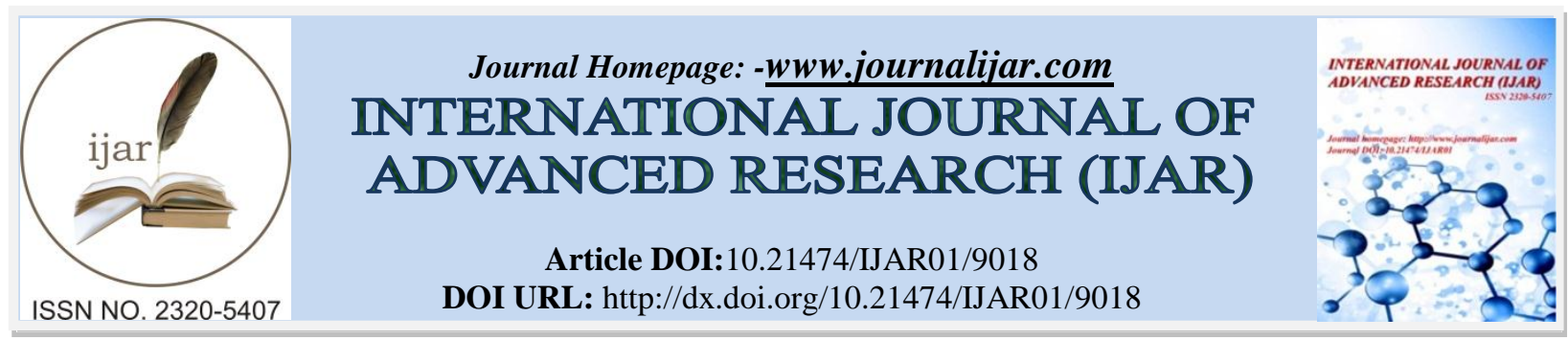

RESEARCH ARTICLE

\title{
PROSPECT OF ORGANIC SUGARCANE CULTIVATION FOR JUICE AND JAGGERY(GUR):A LIVELIHOOD FOR FARMERS OF INDIAN SUNDARBAN DELTA.
}

\author{
Goutam Mahata. \\ Assistant Botanist, Sugarcane Research Station, Bethuadahari, Nadia, Department of Agriculture, Govt. of West \\ Bengal-741126, India.
}

\section{Manuscript Info}

Manuscript History

Received: 04 March 2019

Final Accepted: 06 April 2019

Published: May 2019

Key words:-

Sugarcane, Organic Cultivation, Livelihood, Indian Sundarban Delta.

\section{Abstract}

The Indian Sundarbans Delta (ISD) is a part of the delta of the GangaBrahmaputra-Meghna (GBM) basin and shared between Bangladesh $(\sim 60 \%)$ and India $(\sim 40 \%)$. The ISD spread over about 9630 square kilometer between $21^{\circ} 30^{\prime}$ to $22^{\circ} 40^{\prime} \mathrm{N}, 88^{\circ} 05^{\prime}$ to $89^{\circ} 55^{\prime} \mathrm{E}$.

The ISD covers 6 administrative blocks of the North 24 Parganas district (Haroa, Hansbad, Hingalganj, Minakhan, Sandeshkhali-I, Sandeshkhali-II) and 13 blocks in South 24 Parganas (Basanti, Canning-I, Canning-II, Gosaba, Joynagar-I, Joynagar-II, Kakdwip, Kultali, Mathurapur-I, Mathurapur-II, Namkhana, Patharpatima, Sagar) of West Bengal. The area experiences a subtropical monsoonal climate with an annual rainfall of 1,600-1,800 mm.

Sugarcane (Saccharum sp. hybrid complex) is a vegetatively propagated cash crop in the world as well as in India and the juice extracted from sugarcane is used for making white sugar, brown sugar(Khandsari) and jaggery(gur). Sugarcane has an area of 17 thousand hectare with average yield of 76.1 MT per hectare and total production of 12.94 lakh MT during 2017-18 in West Bengal. Sugarcane can also be eaten as is or consumed in the form of juice, which has huge demand. A glass of sugarcane juice with the touch of lemon and ice makes a popular drink which really life both health and depleting levels of energy. Organic sugarcane juice has a strong defence against cancer, especially breast and prostate cancer. Diabetic patients can also consume sugarcane juice because of low glycemic index (GI). Demands of sugarcane juice can easily be seen by the huge crowd rounding the roadside vendors, waiting a glass of Sugarcane juice. Organic Jaggery(gur) is a better sweetener and having all the ingredients of sugarcane juice in addition to sucrose and has more nutritional value and characteristic flavour because of natural compounds and can be prepared by sugarcane growers with the help of a few skill artisans in a small scale. Installation of sugarcane juice bars/outlets/stalls within the Bus Stands, Hospital campuses, Market places, educational institutes, different government offices, Kishan Mandies, Parks, Tourist Spots, Religious places, etc and organic jaggery(gur) can drastically change the scenario and having opportunities of employment generation as well as increase the income of the farmers in ISD. 


\section{Introduction:-}

Sugarcane (Saccharum sp. hybrid complex) is a vegetatively propagated cash crop in the world as well as in India and the juice extracted from sugarcane is used for making white sugar, brown sugar(Khandsari) and jaggery(gur). It can also be eaten as is or consumed in the form of juice, which has huge demand in West Bengal. A glass of sugarcane juice with the touch of lemon and ice makes a popular drink which really life both health and depleting levels of energy. It is a traditional crop and making jaggery(gur) from its juice important rural based cottage industry in sugarcane growing areas including ISD. In general, hybrid complex of sugarcane varieties cultivated inorganically and huge synthetic chemicals are used, which has adverse effect on biodiversity and ecosystem. As ISD area is rich in biodiversity, organic cultivation of sugarcane is very much important for sustaining and enhancing the health of soil, plant, animals, individuals, communities and ecosystems. Sugarcane has an area of 17 thousand hectare with average yield of 76.1 MT per hectare and total production of 12.94 lakh MT during 2017-18 in West Bengal(SugarIndia, YearBook, 2018).

\section{Nutritional value of Sugarcane Juice:}

Sugarcane juice contains high polyphenols, which are powerful phytonutrients with the qualities of antioxidants. It is also loaded with vitamins and minerals such as calcium, potassium, magnesium, manganese, and iron; along with a complete profile of essential amino-acids that help burn fat and build muscle. Some of these include pipecolic acid, methionine, tryptophan, $\beta$-alanine, and arginine; along with basic amino-acids like histidine, lysine, arginine, and tryptophan. Sugarcane juice is alkaline to the body and most diseases cannot live in an alkaline environment. The juice Sugarcane per serving (28.35 grams) contain Energy-111.13 kJ (26.56 kcal), Carbohydrates-27.51 g, Protein$0.27 \mathrm{~g}$, Calcium11.23 mg (1\%), Iron $0.37 \mathrm{mg}$ (3\%), Potassium $41.96 \mathrm{mg}$ (1\%), Sodium $17.01 \mathrm{mg}(1 \%)$.

1. An Energy Drink - Sugarcane juice is rich in good kind of carbohydrates, protein, iron, sodium, potassium and other essential nutrients that make it the ideal energy drinks. A glass of sugarcane juice with the touch of lemon, peppermint(Mentha piperita) and ice makes a popular drink which really life both health and depleting levels of energy. It builds up plasma and body fluids and helps counter dryness and fatigue. Diabetic patients can also consume sugarcane juice because of low glycemic index(G.I.)

2. Prevent Cancer- May be you have not heard this before; the efficacy of sugarcane juice was a strong defence against cancer. Sugarcane juice is considered an alkaline forming food because of the high concentration of calcium, magnesium, potassium, iron, and manganese in it. Diseases like cancer cannot survive in an alkaline environment and that's why it is effective in fighting cancer, especially prostate and breast cancer. The content of flavonoids in sugarcane juice inhibits the growth of cancer cells in the milk glands.

3. Remedy for Jaundice- According to Ayurveda, sugarcane juice helps strengthen your liver and is thus suggested as a remedy for jaundice. It also protects the liver against infections and helps in keeping the bilirubin levels in control. This is one of the reasons that doctors' advice jaundice patients to drink sugarcane juice.

In addition, it helps the growth of bones \& teeth, solving constipation, maintain weight, use as digestive tonic and cure fever.

\section{Nutritional Value of Jaggery(Gur):}

Jaggery(Gur) contains Sucrose(65-85\%), Glucose,Frucktose(10-15\%), Proteins(0.25\%), Fats(0.05\%), Calcium(0.4\%), Phosphorous(0.045\%), Iron(11mg/100gm), Copper(0.8mg/100gm), Total minerals(0.6-1), moisture(3-10\%) \& Energy(3.83 K.Cal). Organic Jaggery(gur) has more nutritional value and has a characteristic flavour of natural compounds. Compared to Sugar, it is a better sweetener by virtue of it having all the ingredients of sugarcane juice in addition to sucrose but white crystal sugar is only sucrose and all the ingredients go in the byproducts in sugar industry(Keshavaiah, K.V, Swamygowda, S.N \& Thimmegowda, P, 2018)

\section{Major Constrains in Sugarcane cultivation within ISD. Soil Salinity-}

Soil salinity threatens agricultural productivity in 77 mha of agricultural land including 45 mha(20\% of irrigated area) of irrigated and $32 \mathrm{mha}(21 \%$ of dry land) of rainfed area(Munns,2002). The salts that largely contribute to salinity include the chloride and sulphate of sodium, calcium, magnesium and potassium. In such soil the plants are unable to absorb the water and nutrients in adequate quantities due to high osmotic pressure of the soil water. With heavy rainfall a temporary relief of salt stress can be observed due to leaching of the salts from the root zone. 
Sugarcane is ranked moderately sensitive to salinity with a threasold value of $1.4 \mathrm{dSm}^{-1}$ (Maas, 1986). Soil root zone EC below $2 \mathrm{dSm}^{-1}$ have no effect on growth and yield of sugarcane. 5-7.0, the yield decreased by 50\% and at EC of 8.0 stools of some cultivars are killed and do not survive. A yield reduction upto $60 \%$ has been recorded due to salinity(Vasantha, S., 2016). Pale green or yellow leaves, scorched tips and margins, reduced leaf area \& stunted canopy are the symptoms of salt damages.

\section{Effect of salinity on sett germination of sugarcane-}

Generally germination of sett in sugarcane is delayed progressively with increasing salinity and reduction in final germination percentage at high salinity level(EC> $\left.5 \mathrm{dSm}^{-1}\right)$ Varietal response is a critical factor in determining the final germination. During germination and early growth of the crop, nitrogen requirements are more, as sink production is at its peak. Nitrate reductase, an important enzyme in N-metabolism showed significant reduction in salinity treatment(Jasmine Rani et.al., 2004).

\section{Effect of salinity on Yield and Quality characters of Sugarcane-}

Reduction of cane length, girth, number of millabale cane, single cane weight is generally observed due to salinity, which ultimately reduced the cane yield. Sucrose \% juice, brix and purity are reduced by salinity(Vasantha, S., 2016).

\section{Natural Calamity-}

The ISD area is prone to extreme storm events which are frequent during the pre-monsoon period and from September through November. Historical records indicate a high frequency of extreme weather events, such as severe storms or cyclones.

\section{Major parameters to be followed for organic Sugarcane Cultivation in ISD:}

The following parameters need to be addressed before organic cultivation of sugarcane in ISD areas-

\section{Improvement of Soil.-}

Application of gypsum as per soil testing report is allowed in organic cultivation system. Application of crop residue as mulch, organic or bio fertilizers, adoption of crop rotation and multiple cropping, minimum tillage, keeping the soil covered with green cover or biological mulch and abandoned use of synthetic chemicals are most important for improvement of soil in organic production system. Continuous incorporation of crop \& weed biomass, Farm Yard manure (FYM), Vermicompost, special liquid formulations(Compost tea, vermiwash etc.), oil cakes, poultry manure, concentrate manures(mixture of oil cakes, poultry manure, and rock phosphate) etc. are also equally important for improving the soil.

\section{Self-reliance of inputs-}

On farm production of seedcane, composts, vermicomposts, vermiwash, liquid manure \& botanical extracts should be ensured.

\section{Integration of animals-}

Back yard poultry, cattle, piggery, gottary,etc. should be maintained.

\section{Steps in developing organic farm for sugarcane cultivation:}

Organic cultivation of sugarcane crop requires integrated management of essential components in a systematic manner for optimum productivity.

\section{Habitate Development-}

The area of ISD is storm prone, thus various trees and bushes [Neem, Custard Apple, Wood Apple, Guava, Mulberry, Ber,etc.] should be planted surrounding the organic farm. Those trees and bushes are not only protect the sugarcane field from storms but also attract the birds and other beneficial animals and provide food $\&$ shelter for them. Different bio pesticides may be extracted from different parts of the trees and bushes. In border rows of each plots within the farm, Glyricidia/Sesbania, will not only act as biological fence but also provide biologically fixed nitrogen to the soil.

\section{Conversion of soil to organic-}

Application of synthetic chemicals should be banned. Intercropping of different legumes, green manuring, green leaf mannuring, trash mulching, organic farm waste recycling, application of different types of bio fertilizers[Rhizobium, 
Azotobacter, Azospirrilum, Phosphate Solubilizing Bacteria etc], organic liquid fertilizers[vermiwash, panchaygavya] helps for conversion of soil to organic.

\section{Organic Pest Management-}

As synthetic chemicals are prohibited, pest management should be done through-

\section{Cultural/Agronomic-}

Use of sugarcane setts free from pest affected plots and cultivate resistant varieties, manipulating the date of planting, detrashing, earthing up etc

\section{Mechanical/Physical-}

Removal of affected cane and plant parts, collection and destruction of egg masses, use of light traps

\section{Biological-}

Inundative release of Trichogramma chilonis 2cc/acre at fortnightly interval is recommended to manage Gurdaspur borer(Acigona steniellum) and Plassey borer(Chilotumi dicostalis). In case of internode borer, detrashing(at $5^{\text {th }} \& 7^{\text {th }}$ month), release Trichogramma/Cotesia parasitoids and use of pheromone @ 25 traps/ha are recommended(Viswanathan, R, Jayanthi, R and Sankaranarayanan, C. 2017)

Organic sugarcane cultivation incidentally conserves natural enemy complex of pests and keep them under check.

\section{Organic Disease Management-}

Vegetative propagation, practice of ratooning and high sugar accumulation makes sugarcane crop easily susceptible to various diseases in the field. Infected seed canes are responsible for the primary spread of different diseases like red rot, smut, wilt, grassy shoot, yellow leaf disease etc. For organic cultivation, emphasis should be given on using disease free sugarcane setts from disease free seed production plots of resistant varieties.

\section{Special management practices of sugarcane for organic cultivation in ISD areas:}

1. Higher seed rate of $25 \%$ over normal seed rate has to be followed to compensate germination losses and to ensure good germination and crop stand.

2. Irrigation with good quality water at least during critical growth stages upto 150 days of the crop.

3. Following modified trench system of planting with extra organic manure improved yield in saline soil.

4. Crop rotation with tolerant crop like cotton, mustard etc.

5. Proper wrapping \& propping should be practiced and erected the clumps fallen after storms.

6. Growing salt tolerant varieties like Co 94012, Co 99004, Co 85019, Co 0403, Co 0218, BO 91, CoB 99161 etc.

\section{Organic Certification:}

After growing the sugarcane crop for 2-3 years as per the organic standard, one become eligible for applying for organic certification. In India, there are two accreditation system for authorizing certification and inspection agencies for organic certification. National Programme on Organic Production(NPOP) promoted by Ministry of Commerce is the core programme which governs and defines the standards and implementing procedures. National Accreditation Body(NAB) is the apex decession making body. Certification and inspection agencies accredited by NAB are authorised to undertake certification process. The NPOP notified under FTDR act and controlled by Agricultural Processed Foods Export Development Authority(APEDA) looks after the requirement of export while NPOP notified under APGMC act and controlled by Agriculture Marketting Advisor, Directorate of marketing and inspection looks after domestic certification(Sarkar \& Barman, 2018).

\section{Summary:}

The importance of sugarcane for chewing, juice and jaggery(gur) and the demand for them specially on festive occations like Durga Puja, Lakshmi Puja, Kali puja, Makar Sankranti in West Bengal including ISD offers great scope for organic sugarcane cultivation. Installation of organic sugarcane juice bars/outlets/stalls within the Bus Stands, Hospital campuses, Market places, educational institutes, different government offices, Kishan Mandies, Parks, Tourist Spots, Religious places, etc and organic jaggery(gur) making units can drastically change the scenario and having huge opportunities of employment generation as well as increase the income of the sugarcane growers in ISD. 


\section{References:-}

1. Jagannatha Rao, P.K.V. and Sreedevi, P. 2017. Quality jiggery-An option for non traditional sugarcane growing areas. Indian Farming 67(02): 41-44

2. Jasmine Rani, G.M., Vasantha, S., Kanimozhi, K. 2004. Influence of salinity on growth \& biochemical characters during germination phase in sugarcane. Plant Archives 4(2): 447-452

3. Keshavaiah, K.V, Swamygowda, S.N and Thimmegowda, P. 2018. Jaggery-A livelihood for farmers in Cauvery Command Area, $32^{\text {nd }}$ biennial workshop, AICRP on sugarcane, 17-18 october, UAS, GKVK, Bengaluru: p 8897

4. Maas, EV. 1986. Salt tolerance to Plants. Applied Agricultural Research 1:12-26

5. Munns, R. 2002. Comparative physiology of salt and Water Stress. Plant Cell Environ: 25,239-250

6. Prakash, O. 2005. Cultural history of India. New Age International. P.516

7. Sarkar \& Barman, 2018. Training Mannual: Directorate of Extension, DAC\&FW, MoA\&FW, sponsored Model Training Course on "Capacity Building of Extension Personnel on Advance Organic Technologies \& its Promotion through Innovative Extension Approaches"(October 22-29, 2018), ICAR-Indian Agricultural Research Institute, Regional Stations, Kalimpong, West Bengal-734301.

8. SugarIndia Year Book, 2018. www.anekantprakashan.com

9. Vasantha, S. 2016. Abiotic stress management in sugarcane. Hand Book on Sugarcane, ICAR-SBI, Coimbatore:141-164

10. Viswanathan, R, Jayanthi, R and Sankaranarayanan, C. 2017. Integrated disease and pest management in sugarcane. Indian Farming 67(02): 28-32. 